Radmila Micić ${ }^{1}$

University of Priština, Faculty of Economics
SCIENTIFIC REVIEW ARTICLE doi:10.5937/ekonomika1504047M Received: September 17, 2015 Accepted: October 13, 2015

\title{
LEADERSHIP ROLE IN CERTAIN PHASES OF KNOWLEDGE MANAGEMENT PROCESSES
}

\begin{abstract}
Leader has a crucial role in the process of knowledge management. In order to be successful, leader has to possess qualities and skills that create the conditions for creating, sharing and use of knowledge in organizations. However, apart from the creation, transfer and use of knowledge, it is essential that it promotes and creates new knowledge that will contribute to creating value for the organization. The aim of this work is to point out the necessity of knowledge management, and to suggest the styles of leadership at various stages of knowledge management. The research is of theoretical nature and method of analysis will be used. In this paper we will firstly describe leadership styles. Then we will expose phase of the process of knowledge management. Finally, we describe the role of the leader in the individual stages of the process of knowledge management. By analyzing the styles of leadership and phases of knowledge management process, we have found that the roles and tasks of leaders differ in the stages. Therefore, it is necessary to apply different leadership styles. According to this, different stages of the process of knowledge imply different styles of leadership.
\end{abstract}

Key words: leadership, style of leadership, knowledge management

JEL classification: M21, M12

\section{УЛОГА ЛИДЕРА У ПОЈЕДИНИМ ФАЗАМА ПРОЦЕСА УПРАВЉАЫА ЗНАЫЕМ}

\begin{abstract}
Апстракт
Лидер има круцијалну улогу у процесу управљања знањем. Да би био успешан, лидер треба да поседује особине и способности које стварају услове за креирање, размену и употребу знања. Међутим, сем стварања, трансфера и употребе знања, неопхоно је да се оно унапређује и ствара ново знање које ће допринети креирању вредности за организацију. Циљь овог рада јесте да укаже на неопхоност управљања знањем, као и да предложи стилове лидерства по појединим фазама управљана знањем. Истраживање је теоријског карактера и користиће се метода анализе. У раду ћемо, најпре, описати стилове лидерства. Затим ћемо изложити фазе проиеса управљања знањем. На крају, описујемо улогу лидера у појединим фазама проиеса управљања знањем. Анализирајући стилове лидерства и фазе процеса управљања знањем утврдили смо да се улоге и задаџи лидера
\end{abstract}

${ }^{1}$ radmila.micic@pr.ac.rs 
разликују по фазама. Стога је неопходно применити различите стилове лидерства. Према наведеном, различите фазе прочеса управљања знањем имплицирају различите стилове лидерства.

Кључне речи: лидерство, стилови лидерства, менаумент знања

\section{Introduction}

The interest in leadership and knowledge, as a certain phenomenon of business success in modern organizations, becomes more and more actual and significant. Leadership is the most frequently researched processes of organizational behavior and management which have marked the end of the $20^{\text {th }}$ century and the beginning of the $21^{\text {st }}$ century. Leadership is often described as a process through which an individual has influence on the group to obtain common goals (Northouse, 2013, p. 5). Leaders have an important role in their organizations. They have influence on the performance of their team (Pirola-Merlo, et al, 2002). The power of leadership and leaders can be seen in the effect of their ideas, abilities to motivate and inspire their associates to accept changes, to constantly acquire knowledge and to share it with other members of organization. Modern society is the one which is founded on knowledge. Nowadays, knowledge is the most wanted merchandise, the most valuable resource of an organization and the source of its competitive advantage. Knowledge is a factor of vitality, innovation of an organization and driving force which affects efficient usage of all the resources in organization. Knowledge is the only resource which is not diminished by sharing; rather, by using and sharing it, the overall knowledge of organization is expanded. Management of knowledge represents the process which starts with the creation of knowledge, than it is expanded through organization, memorized and at the end, that knowledge is used. Without efficient leadership, there is no efficient knowledge management. So, a leader is the one who should create organization which provides conditions for creation, sharing, using and acquiring new knowledge in organizations.

The goal of this work is to point out the necessity of knowledge management, as well as to suggest the styles of leadership through certain phases of knowledge management. The basic hypothesis, we start with in this work is that the roles, tasks and leadership styles are different according to phases of knowledge management process. Apart from this, in the work, we start from the point that: leadership has a key role in producing organizational performances, leadership is the most valuable property of a company which makes a difference among successful and unsuccessful organizations, a leader has a crucial role in knowledge management, knowledge represents the most valuable resource of organization. This work is of theoretical character and the method of analysis will be used. The work consists of three parts. In the first part, the styles of leadership will be described: charismatic, transformational, team and network leadership. The second part describes the process of knowledge management through phases of: identify, store, share, use, learn, improve and create. Third part analyzes the role of the leader according to certain phases of knowledge management; his tasks, characteristics, skills and abilities, and suggests the style of leadership which will be most suitable for a certain phase. 


\section{Leadership styles}

Charismatic leadership. The word charisma originates from the Greek word $\chi \alpha \dot{\alpha} \iota \sigma \mu \alpha-\mathrm{a}$ gift and signifies a rare characteristic of human beings to possess great charm, attractive personality and sometimes a strong ability of persuasion and unforced directing of the course of conversation in desirable direction. (www.Wikipedia.org/sr/ harizma). Charisma, as a dominant characteristic of a leader was firstly affirmed by Weber, defining it as a „certain characteristic of individual personality thanks to which he or she is distinguished among common people and is treated as having supernatural, superhuman or at least certain extraordinary powers and characteristics "(Robbins \& Judge, 2010, p. 431). Later, Robert House developed a theory of charismatic leadership, according to which the followers ascribe to individuals heroic or extraordinary abilities of leadership when they notice certain types of behaviour.

According to House's theory, important characteristics of charismatic leader are (Stoner \& Freeman, 1992, p. 501):

- extremely high level of self-respect,

- high level of domination and

- strong belief in personal attitudes

Key characteristics of charismatic leader are (Conger \& Kanungo, 1998, p. 94):

- Vision and articulation. They have vision as an ideal goal which proposes a better future, and they can explain significance of that vision with the concept which is clear to anyone.

- Personal risk. Readiness to take over high risk and devotion to achieve that vision.

- Sensitivity to followers' needs. Perception about abilities of others and reacting to their needs, feelings and unconventional behaviour. Maintaining behaviour which is considered unusual and is confronted with the norms.

Thus, charismatic leader is a person who has a clear vision, ability to express vision, great capacity to influence his followers, self-confidence, ability to implement changes, motivate followers and take on risks. Leader with mentioned characterisitics has great influence on the satisfaction of his followers and achieving high performances of an organization. Business with charismatic leader motivates people to make more effort at work and devote themselves more to the realization of ideas which their leaders represent. The role and significance of a charismatic leadership is dominantly expressed in critical situations, conditions of uncertainty and risk, and in the need to implement quick and radical changes in organization.

Transformational leadership.Transformational leadership represents the highest level in the leadership development and it incorporates the following leader skills: idealized influence (leader enables vision and the sense of a mission, implants pride, gains respect and trust); inspirational motivation (leader communicates high expectations and expresses important intentions in a simple way); intelectual stimulation (ability of a leader to promote intelligence, rationality and careful problem solving) and individual consideration (leader treats every individual separately, pays attention to him or her, instructs and advises) (Bass, 1990, p. 19-31):

Transformational leadership purports concern for the development of creativity and innovation of followers and development of their potential. Transformational leaders motivate followers to surpass personal interests for the benefit of organization, motivate them to work more then they are expected to, encourage the sense of task significance 
that should be done for the prosperity of organization as a whole. By applying the transformational leadership style, followers make an additional effort, acomplish greater productivity. The sense of satisfaction with the followers is increased, fluctuation and absentism is decreased, which leads to high performances of organization.

Transformational leader should have specific characteristics such as (Galpin, 1996, p. 70):

- Agent of change qualities. Important characteristic of transformational leader is to encourage and carry out changes and successfully design flexible, entrepenureal and innovative organizations.

- Courage. Transformational leaders take risks.

- Candidness and belief in followers. They are characterized by candidness, sincerity and belief in followers by which they tend to include them in the process of decision making.

- They are guided by values. These leaders create a set of values that should be aspired to and they behave in accordance to them.

- Life-long learning. They are capable to change their behaviour, values and attitudes radically, if the circumstances demand to.

- Ability to face complex, ambiguous and uncertain situations. They are characterized by ability to face every situation and solve unstructural problems.

- Visionary abilities. Transformational leaders are capable to create vision, to interprete it successfully to their followers and encourage them to realization of such formed picture of a future desired state of organization.

We will add the following to the mentioned characteristics of transormational leader:

- Creativity. They are creative, but they encourage and accept creativity of their followers.

- Team orientation. Transformational leaders create teams, affirm the significance of team work and exchange of ideas, opinions and attitudes among the team members.

- Appreciating others. Tansformational leaders acknowledge and value attitudes and opinions of their followers. They have the skill to listen and encourage two-way communication.

- Tutoring. Transformational leaders are tutors, they instruct, correct and direct their followers.

- Responsibility. Important characteristic of these leaders is taking risks and responsibility.

- Credit. They give credit and praise to their followers for successfuly completed activity.

Team leadership. In modern business conditions, teams are affirmed, so team leadership gains on actuality and significance. Team leader is faced with numerous challenges in: creating and leading teams, building trust, transfer of information, giving autonomy to team members, authority assignment, intervention time and so on. Important roles of team leader (Robbins \& Coutler, 2005, p. 435):

- Connection with the outside world. This role of a leader is reffered to the higher levels of management, other inner teams, clients and suppliers. Leader presents to other groups, provides neccessary resources, explains expectancies 
of others, collects informations from the surroundings and forwards them to the team members.

- Team leader solves problems. Leader should solve conflict situations, he helps and mediates with the problem solving in the team.

- Leader manages conflicts. Leader has a task to define the problem, discover source of the problem, identifies participants of the conflict, offer strategies for solving conflict situations.

- Teachers. Team leaders explain expectancies and roles, teach, support, encourage and help team members to improve their performancies.

Network leadership. Business globalization, fast changes and usage of informationcommunication technologies have initiated the appearance of network leadership. In order to respond to survival challenges, leaders must build skills of work in the network, connect with the followers which are often physically separated. Communications through e-mail, absence of face to face contact and non-verbal communication demand additional skills and abilities from the leader. Writing skills, writing style, ability to „read between the lines" and using of modern technologies become prominent.

Generally speaking, characteristics of a leader with good network skills can be divided into: basic characteristics, relationship towards the members of the network, administrative characteristics and other characteristics (Raz, 2003, p. 90-98).

Some of the basic characteristics of good network leader would be: she/he constantly develops his network; he builds network before he needs it; circle of people he/she is connectected to is varied and he/she constantly expands it; he is a member of many groups, associations, clubs; he completes his network with his members' networks; when he has a problem, he can turn to the best person in the profession. He can turn to any member of his network when he needs to; he encourages members of his network to develop their own networks; he collects information in advance about interests, needs and common ground with the persons he is about to meet.

Good network leader constantly builds good relationship with the members of his network. He: cares about people, learns about them, listens to them, spends time with them, pays attention to them and helps them. He always builds and wins over trust of his network members. He is always in contact with them and attends all important events. He organizes socializing and gathering of his network members.

\section{Knowledge management}

Knowledge management is a process of organizational performances promotion through creating and applying the process, system, structure and culture that supports creating, exchange and usage of knowledge (Delong \& Fahey, 2000, p. 113). For the efficient inclusion of knowledge management system, it is neccessary to provide adequate context which incorporates: „culture, knowledge assesment, knowledge processing and knowledge implementation" (Award \& Ghaziri, 2004, p. 60). Knowledge management is often described as a process in which knowledge is created, won, storaged, shared and applied (Mašić, 2010, p. 501). „Knowledge management is the explicit and systematic management of vital knowledge- and it is associated with the processes of creation, diffusion, use and exploitation- in pursuit of business objectives“" (Skyrme, 2011).

The process of knowledge management is completed through phases and it pervades the whole organization. Evans, Dalkir \& Bidian (2014) mention seven phases 
of management learning process, and they are: ,identify, store, share, use, learn, improve and create" (p. 91). These phases will be explained in the following text.

Identify. The need for knowledge can arise for many reasons, whether it is solving strategic or operative problems, making decisions, analisys of knowledge gap or the need for innovations. If there is the need for knowledge, it should be established whether it can be identified within an organization or it should be created/acquired. Sometimes, there is the need for identification of existing knowledge property, but also for creation of new knowledge. Identification of knowledge. The phase of identification includes codifying of existing knowledge property. Knowledge can be taken from knowledge storage through the form of electronic or printed documents. In this phase, implicit knowledge can be identified through the method of brainstorming and discussion sessions. The phase of identification includes analysis and assessment of knowledge property which is based on established organizational culture, values and attitudes, as well as specific organizational rules. During the analysis and assessment of knowledge property, it is important to determine relevant information which can contribute to problem solving.

Store. Organizational knowledge represents important resource of organization and it has to be saved, memorized and available to all the organization members. In that way, connection between organization members becomes stronger and they become aware of their significance in creation of new knowledge. In this process, knowledge can be modified and improved. When knowledge is founded as an important value of organization, based on analysis and assessment in the phase of identification and creation, it is kept as an active component in organization memory. For this, more forms of codified knowledge may have been needed. Many forms of tacit knowledge can be saved in the form of maps, models, nomenclatures, documents. However, knowledge storage can't be accidental collection of knowledge property, no matter of its individual or collective value. Knowledge asset must be saved in a structured way which enables efficient using, manipulating, sharing. Main steps in the system of knowledge saving would be: a) identification of real problem; b) identification of knowledge that should be saved and in a certain form; c) defining the process of saving and tracking knowledge and the role of employees in acquiring knowledge; d) integration of the process of saving knowledge; e) adjusting the documents of knowledge to the hierarchal structure and creating documents in accordance to the rules of memorization process and saving knowledge; f) supervision and follow up of feedback and knowledge transfer through organization (www.powerdocuments.com/knowledgeretention.pdf.).

Share. The next phase in the process of knowledge management is knowledge sharing, or difussion of knowledge in organization. In this phase, expanding of existing and new knowledge through organization is present. Knowledge should be available to everyone, otherwise it becomes useless.

Knowledge property is taken over from organizational memory, and it is further distributed inside or outside organization. Frequency of knowledge sharing can be established in advance or ad hoc, according to usage. The process through which knowledge is shared is important, because employees are rarely aware of their existance, especially when new knowledge is created. It is not unusual for organizations to look for knowledge outside their boundaries. Existance of explicit, dynamic and flexible network of expertise encourages cooperation and it can contribute a lot to the exchange of organizational knowledge property. Explicit knowledge can be easily shared with others. Problem appears when implicit knowledge should be shared. For that purpose, it is desirable to develop direct communication between the organization members, as to develop discussion and exchange of knowledge. Then, forming of so called „mutual practice“, as an informal group of people inside organization which solves problems for 
which it has knowledge, expertise, skills and experience. Division of implicit knowledge can be stimulated through programs of instruction and mentoring, as well as narration and anegdote. It is also important to choose optimal combination of technology and channels for information sharing, because different media of communication have their advantages and disadvantages. The choice of media is not just a function of specific expert services, but it also depends on the maturity of knowledge management in organization. Technologies that are most often used for sharing of knowledge property include communication and cooperation between technology and current clients, management of supplier chain and systems for decision support.

Use. Existing knowledge property can be used for problem solving, decision making, improvement of business efficiency in organization and so on. In an organization, there is always a level of tacit knowledge which can be applied. The larger and more complex knowledge property is, the harder is to „unpack“ value out of it. So, in order for that knowledge to be efficiently applied, it is sometimes necessary to hire experts. The phase of using the knowledge is a key for integration of tacit knowledge forms. Conversion of explicit into implicit knowledge is applied through different methods of employee trainings, such as: simulation, active learning, gaining experience at work and so on. In the phase of knowledge usage, different workshops and communities for pratice can be formed. Employees use expert systems, modern communication technology and cooperation for the realization of mentioned activities.

Learn. Knowledge property which was shared and used in the previous phases can be used as a basis for creation of new and improved knowledge property. Knowledge usage leads to gaining experience of employees, because they interprete the influence of knowledge in their working environment. If the existing knowledge property is insufficient, it is necessary to intensify the phase of identification and knowledge creation. In that way, double circle of learning is put into practice and life cycle of knowledge starts over. In the phase of learning, following activities are used: benchmarking, mutual practice, lessons from the past, knowledge gap analysis and so on.

Improve. Learning which takes place in the previous phase leads to further refinment of knowledge property. Knowledge which is identified or created should be saved in organizational memory and applied according to usage. In this phase it is very important to save improved knowledge property, so it can be efficiently used in the future. In this phase, critical decision is made whether to keep improved knowledge in organization or take it outside organization for further use.

Create. If necessary knowledge hasn't been found, during research into identification phase there is the need for creating new knowledge property. Need for creating new knowledge property can appear when existing knowledge property only partially satisfies need for knowledge. Mutual organizational initiatives which help creation of new knowledge property include: expert interviewing, building prototypes, information and analysis about the work process, competency and process mapping.

\section{Role and Characteristics of a Leader in Certain Phases of Knowledge Management Process}

In the phase of knowledge identification, a leader should create organizational environmnet and culture which supports organizational and team learning. Leader should support and encourage learning with his behaviour and direct organization members' effort to learn. Leader as a teacher helps people in organization to develop system understanding, 
expand their capacities in order to understand complexity, make vision clear and improve mutual mental models. The task of a leader is to create organizational environment which is good for learning and to implement cultural values of learning and development in the awareness of employees. It is very important to develop culture in which employees share their knowledge and cooperate with others. A leader should support team learning and work and not individual domination. Favourable climate in organization is the one of cooperation, exchange of ideas and attitudes through dialogue which leads to constructive problem solutions. It means that in this phase a leader should have ability to encourage learning, ability to interprete and share his own experience, ability to create environment for learning and encourage creative dialogue. In order to achieve that, a leader should have characteristics of charismatic, transformational and team leader.

The role of the leader in the phase of storage knowledge is of crucial importance both from the aspect of saving knowledge in the bases of knowledge and in making decisions about the level of knowledge which should be dislocated outside organization. In each process of saving knowledge, the role of a leader is important in building confidential organizational culture, establishing hierarchy of information and knowledge, strengthening of communication networks which can provide efficient exchange of information and knowledge. In times when different forms of network design are formed, especially critical moment is making decision about the level of knowledge which should be kept in order to improve its own competency and the level of knowledge which can be dislocated outside organization. Such decisions can have long term consequences for organization survival. The task of a leader is to identify knowledge which should be kept and in a certain form, to suggest the importance of collective knowledge and knowledge saving. The process of knowledge saving demands from a leader to have skills for networking, to be a team leader, to be charismatic and to have capability of a transformational leader.

In the phase of knowledge sharing a leader should create culture of knowledge sharing through: a) building connection between knowledge sharing and practical business goals; b) adjusting the style of organization with the way of implementation of knowledge sharing culture; c) promotion of awards and praise to people who contribute to the development of knowledge sharing culture; d) providing resources which will help the development of network for sharing knowledge between the organization members; e) connecting knowledge sharing with the values of organization; f) encouraging individuals who can transfer knowledge from one to the other; g) connecting organization members who already share ideas and knowledge in organization (McDermott \& O'Dell, 2001, p. 76-84). In this phase, the role of a leader is important in forming mutual practice, encouraging organization members to exchange ideas, encouraging to have dialogues and discussions. In this phase, a leader should have characteristics of transformational, charismatic, team leader and network leader.

The role of a leader in the phase of knowledge usage. Acquiring, storage and knowledge sharing are needed, but not sufficient conditions for increasing the value of organization through the process of knowledge management. For successful establishing the process of knowledge management, the use of existing, won, created, saved knowledge is needed. Application of knowledge should be a part of every-day activities of all employees. Lessons learned in the past can do good for solving similar problems in the future. In the phase of knowledge usage, the task of a leader is to perform all necessary activities in order to use that knowledge. His role in creating systems of awarding organization members who have shared their knowledge with others and the ones who contributed to application of knowledge with their activities is especially important. A leader should create a climate of innovation and creativity which will contribute to improvement of individual and collective knowledge. Furthermore, a leader should improve communication channels and refresh 
knowledge base. For performing of these tasks, a leader should have conceptual skills, to be a good team leader, motivate, mobilize and inspire his associates. So, he has to have characteristics of transformational, charismatic and team leader.

In the phase of learning, a leader should encourage and support the culture of team and organizational learning. Sengi (2003) points out that „organizations which will trully advance in the future will be the ones which will discover how to encourage human commitment and ability to learn at all the levels in one organization" (p. 8). Successful leaders encourage learning and direct effort of organization members to learn and share their knowledge with others, implement cultural values of learning and development in the awareness of employees, build the climate of trust, good interpersonal relations and are tolerant to mistakes (Micić, 2010, p. 52). The task of a leader is to perform techniques of acquiring new knowledge, form team of experts for acquiring new knowledge. In this phase, also, the role of a leader is very important - of such a leader who possesses characteristics of charismatic, transformational and team leader.

In the end, in the phase of improvement, it is demanded from a leader to have all those characteristics which we have mentioned at the phase of saving, sharing and applying knowledge. Based on that, in this phase as well, characteristics of transformational, charismatic, team leaders and network leaders are needed.

Research results about the role of leadership in knowledge management process in Serbia show dominant role of a leader in providing knowledge in organization. Over $90 \%$ of interviewed people supported the attitude that leader knowledge and skills are obtained through training and learning and that they can be transferred by implicit or explicit mechanisms. Interviewees appreciate the leaders whose success is founded on expertise more than they appreciate the leaders whose success is founded on their charisma. The research has shown that the leader role is greater in creating good environment for learning through the application of motivation mechanisms, than the direct contact with the leader. In the process of creating and knowledge transfer through organization, a leader should provide conditions for information exchange, good communication, instruction and training of employees (Petković, Aleksić \& Božinović, 2011, p. 13-16).

\section{Conclusion}

We have shown theoretical aspect of leadership styles in this work, the phase of knowledge management and the role of a leader in knowledge management process. We have established that in different phases of knowledge management process, a leader performs different tasks, so, according to that, it is necessary for him to have adequate characteristics, skills and abilities. We have shown that each of the mentioned phases needs different approach, so, the leader role is different and leadership style should be adapted to each phase one at a time. With this, we have confirmed the starting point of the work.

In modern business conditions, leadership and knowledge become the most valuable resources of organization. A leader has a very important role in organizational knowledge management. With his behavior, values, attitudes, characteristics, skills and abilities, he greatly influences the creation of organizational knowledge. He has an important role in creating environment which encourages individual and team learning. A leader should support and encourage the culture of creating, sharing, usage, promotion and acquiring new knowledge in organizations.

Future research should be directed towards the practical review of theoretical postulates. 


\section{References}

Award, M., \& Ghaziri, M. (2004). Knowledge Management. Pearson Education International. Prentice Hall, New Jersey.

Bass, B. (1990). From transactional to transformational leadership: Learning to share the vision. Organizational Dynamics, 18 (3), 19-31.

Conger, J. A., \& Kanungo, R., N. (1998). Charismatic Leadership in Organizations. Sage, Thousand Oaks. CA.

DeLong, D., \& Fahey, L. (2000). Diagnosing Cultural Barriers to Knowledge Management. Academy of Management Executive, 14, 113-126.

Evans, M., Dalkir, K., \& Bidian, C. (2014). A Holostic View of the Knowledge Life Cycle: The Knowledge Management Cycle (KMC) Model. The Electronic Journal of Knowledge Management, 12 (2), 85-97. Retrieved April 4, 2015, from http:// www.ejkm.com/issue/download.html?idArticle=563

Galpin, T. (1996). The Human Side of Change: A Practical Guide of Organizational Redesign. Jossey Bass Publishers, San Francisco.

Mašić, B., et al. (2010). Menadžment: Principi, Koncepti i Procesi. Univerzitet Singidunum, Beograd.

McDermott, R., \& O’Dell, K. (2001). Overcoming cultural barriers to sharing knowledge. Journal of Knowledge Management, 5 (1), 76-84.

Мицић, Р. (2010). Лидерство у организацији која учи. Економика, 56 (3), p. 45-55.

Northouse, P. (2013). Leadership: Theory and practice. Sage Publications, Inc., Thousand Oaks, CA.

Petković, M., Aleksić, A., \& Božinović, I. (2011). Korporativno liderstvo i menadžment znanja. Sociologija, 53(1), 13-16.

Pirola-Merlo, A., Härtel, C., Mann, L., \& Hirst, G. (2002). How leaders influence the impact of affective events on team climate and performance in R\&D teams. The Leadership Quarterly, 13, 561 - 581.

Raz, T. (2003). The 10 Secrets of a Master Networker. Inc.magazine, 25 (19), 90-98.

Robbins, S., \& Coutler, M. (2005). Menadžment. Data Status, Beograd.

Robbins, S., \& Judge, T. (2010). Organizacijsko ponašanje. Mate, Zagreb.

Sengi, P. (2003). Peta disciplina-umeće i praksa organizacije koja uči. Adižes MC, Novi Sad.

Skyrme, D. (2011). „Definition“, Retrieved May 5, 2015, from http://www.skyrme. $\mathrm{com} / \mathrm{kmbasics} /$ definition.htm

Stoner, J. \& Freeman, R. (1992). Management. Prentice Hall Inc., New Jersey.

http:// www.powerdocuments.com/knowledgeretention.pdf. White Paper Knowledge Retention: How to manage knowledge in small and mid - size companies (17. 5. 2015)

http://www.wikipedia.org/sr/harizma (10. 5. 2015) 